\title{
PENGEMBANGAN MEDIA PEMBELAJARAN VIDEO TUTORIAL INTERAKTIF MENGGUNAKAN APLIKASI CAMTASIA STUDIO DAN MACROMEDIA FLASH
}

\author{
Rasyid Hardi Wirasasmita ${ }^{1}$, Yupi Kuspandi Putra ${ }^{2}$ \\ ${ }^{1,2}$ Program Studi Pendidikan Informatika, \\ Fakultas Keguruan dan Ilmu Pendidikan, Universitas Hamzanwadi \\ Email : rasyidhw.p.informatika@gmail.com ${ }^{1}$, Yupi.putra@gmail.com ${ }^{2}$
}

\begin{abstract}
Abstrak
Penelitian ini merupakan penelitian R\&D (research and development) yaitu model pembelajaran berbasis video $\mathrm{CD}$ tutorial interaktif pada mata kuliah bahasa pemrograman visual yang lebih bersifat lihat, dengan dan praktikan. Maksudnya, merupakan pengembangan dari model bahan ajar dalam bentuk lain, yang sifatnya melengkapi bahan ajar yang sudah ada. Aplikasi ini menyajikan materi secara interaktif disertai animasi, audio, video dan dilengkapi dengan evaluasi berupa latihanlatihan soal menggunakan aplikasi camtasia studio dan macromedia flash. Hasil yang akan dicapai dari pembuatan media pembelajaran ini adalah bahwa mahasiswa dapat memahami matakuliah Bahasa pemrograman visual serta mengetahui kualitas dari video $\mathrm{CD}$ tutorial interaktif tersebut berdasarkan penilaian ahli media, ahli materi dan pembelajaran. Hasil penilaian kelayakan media pembelajaran video tutorial untuk matakuliah bahasa pemrograman visual adalah: (1) persentase skor penilaian dari ahli materi sebesar $81,25 \%$; (2) persentase skor penilaian dari ahli media sebesar 84,5\%; (3) persentase skor tanggapan dari mahasiswa sebesar 84,83\%. Berdasarkan hasil penilaian dan tanggapan yang diperoleh tersebut dapat disimpulkan bahwa media pembelajaran video tutorial pada matakuliah bahasa pemrograman visual delphi ini layak untuk digunakan dan dikembangkan.
\end{abstract}

Kata Kunci: Media pembelajaran, Video Tutorial Interaktif, Camtasia Studio, Macromedia Flash.

\begin{abstract}
This research is an $R \& D$ (research and development) research that is an interactive tutorial video $C D$-based learning model in visual programming language courses that are more seen, with and practiced. That is, is the development of a model of teaching materials in other forms, which are complementary to existing teaching materials. This application presents material interactively with animation, audio, video and is equipped with an evaluation in the form of practice questions using the Camtasia Studio and Macromedia Flash applications. The results that will be achieved from the making of this learning media is that students can understand the subjects of visual programming language and find out the quality of the interactive video CD tutorial based on the assessment of media experts, material experts and learning. The results of a feasibility assessment of video tutorials learning media for visual programming language subjects are: (1) the percentage score of material expert assessment was $81.25 \%$; (2) the percentage score of media expert assessment was $84.5 \%$; (3) the percentage score of student response was $84.83 \%$. Based on the results of the assessment and responses obtained, we can conclude that this instructional media of video tutorials on programming language of visual delphi is feasible to be used and developed.
\end{abstract}

Keywords: Learning Media, Interactive Video Tutorial, Camtasia Studio, Macromedia Flash.

\section{PENDAHULUAN}

Teknologi terutama multimedia mempunyai peranan penting dalam proses pembelajaran. Banyak orang percaya bahwa multimedia dapat membawa pada situasi belajar yang menyenangkan, kreatif, dan tidak membosankan. Dalam proses pembelajaran, selain guru dan siswa, dua unsur yang sangat penting adalah metode pembelajaran dan media 
pembelajaran. Penelitian Setiabudi (2005), Alfiah (2008) dan Purbaya (2010) merupakan penelitian sejenis yang membahas pengembangan multimedia interaktif. Lima peneliti tersebut pada intinya menyimpulkan bahwa media pembelajaran yang interaktif dapat memberikan efektifias pada pembelajaran. Camtasia Studio dan Macromedia Flash merupakan software komputer yang bisa dijadikan sebagai media pembelajaran. Namun, masih banyak dosen pendidikan informatika yang belum memanfaatkan software tersebut sebagai multimedia pembelajaran interaktif. Fungsi program Camtasia Studio adalah membuat video tutorial interaktif, sedangkang Macromedia Flash berfungsi untuk membuat tombol-tombol navigasi untuk menjalankan video yang sudah dibuat,dan lainnya.

Bersdasarkan hasil observasi dilingkungan STKIP Hamzanwadi Selong, penggunaan media pembelajaran dengan menggunakan tutorial pembelajaran masih kurang sehingga untuk mengatasi hal tersebut, maka diperlukan media pembelajaran yang dapat menunjang proses belajar mengajar, sehingga dosen tidak lagi kesulitan dalam menjelaskan materi dan tidak selalu menggantungkan demonstrasi tetapi bisa diganti dengan media pembelajaran video tutorial tentang bagai mana membuat produk yang bisa di putar berulang-ulang.

Penggunaan media pembelajaran video tutorial ini akan membantu dan mempermudah proses pembelajaran untuk mahasiswa maupun dosen. Mahasiswa dapat belajar lebih dahulu dengan melihat dan menyerap materi belajar dengan lebih utuh. Dengan demikian, dosen tidak harus menjelaskan materi secara berulang-ulang sehingga proses pembelajaran dapat berlangsung lebih menarik, lebih efektif dan efisien. Dengan petimbangan di atas, maka perlu diadakan penelitian tentang peningkatan kualitas pembelajaran pada mata kuliah pemrograman visual menggunakan media pembelajaran dalam bentuk media pembelajaran video tutorial.

Dari uraian diatas peneliti mencoba mengembangkan media pembelajaran berupa CD pembelajaran multimedia tutorial interaktif. Media pembelajaran ini dapat digunakan sebagai media pembelajaran bagi mahasiswa dan mempermudah dosen dalam menyampaikan materi.

\section{TINJAUAN PUSTAKA \\ Media Pembelajaran}

Kata media berasal dari bahasa latin medium yang secara harafiah berarti tengah, perantara atau pengantar. Secara khusus pengertian media dalam proses belajar mengajar lebih cenderung diartikan sebagai alat tulis grafis, fotografis, atau elektronik untuk menangkap, memproses, dan menyusun kembali informasi visual atau verbal (Arsyad, 2011: 3). Criticos (dalam Daryanto, 2011: 4) "Media merupakan salah satu komponen komunikasi, yaitu sebagai pembawa pesan dari komunikator menuju komunikan".

Berbagai pendapat para pakar pendidikan diantaranya Briggs, Gagne \& Reiser memberikan pengertian tentang media pembelajaran yang dapat dirangkum sebagai berikut (Ilmawan, 2004).

1. Media pembelajaran merupakan alat fisik yang dapat menyajikan pesan serta merangsang peserta didik untuk belajar.

2. Media pembelajaran sebagai alat dimana pesan - pesan istruksional dikomunikasikan.

3. Media pembelajaran merupakan alat aik yang berbentuk hardware maupun software yang digunakan sebagai media komunikasi dan bertujuan untuk meningkatkan efektivitas proses pembelajaran.

\section{Multimedia Interaktif}

Multimedia interaktif adalah suatu multimedia yang dilengkapi dengan alat pengontrol yang dapat dioperasikan oleh pengguna, sehingga pengguna dapat memilih 
apa yang dikehendaki untuk proses selanjutnya. Contoh multimedia interaktif adalah pembelajaran interaktif, aplikasi game (Daryanto, 2011:49). Sementara itu, National Education Associaton (dalam Arsyad, 2006 : 5) memberikan definisi media sebagai bentuk-bentuk komunikasi baik tercetak maupun audio-visual dan peralatannya; dengan demikian media dapat dimanupulasi, dilihat, didengar atau dibaca. Peranan media dalam proses pembelajaran yang diungkapkan oleh Sudjana dan Rivai (2005 : 6-7) antara lain adalah:

1. Alat untuk memperjelas bahan pengajaran pada saat guru menyampaikan pelajaran. Dalam hal ini media digunakan guru sebagai variasi penjelasan verbal mengenai bahan pengajaran.

2. Alat untuk mengangkat atau menimbulkan persoalan untuk dikaji lebih lanjut dan dipecahkan oleh peserta didik dalam proses belajarnya. Paling tidak guru dapat menempatkan media sebagai sumber pertanyaan atau stimulasi belajar.

3. Sumber belajar bagi peserta didik, artinya media tersebut berisikan bahan- bahan yang harus dipelajari peserta didik baik individu maupun kelompok. Dengan demikian akan banyak membantu tugas guru dalam kegiatan mengajarnya.

\section{Video Tutorial}

Pada Kamus Besar Bahasa Indonesia (2001: 1230), tutorial adalah (1) Pembimbingan kelas oleh seorang pengajar (tutor) untuk seorang mahasiswa atau sekelompok kecil mahasiswa, (2) Pengajaran tambahan melalui tutor. Selanjutnya Riyana (2007: 2) menjelaskan bahwa media video pembelajaran adalah media yang menyajikan audio dan visual yang berisi pesan-pesan pembelajaran baik yang berisi konsep, prinsip, prosedur, teori aplikasi untuk membantu pemahaman terhadap suatu materi pembelajaran.

Selanjutnya Smaldino, Lowther, dan Russell (2011: 404-406) menjelaskan bahwa video tersedia untuk hampir seluruh jenis topik dan untuk jenis pemelajar di seluruh ranah pengajaran kognitif, afektif, kemampuan motorik, interpersonal. Mereka bisa membawa para pembelajar hampir kemana saja memperluas minat siswa melampaui dinding ruang kelas. Benda-benda yang besar untuk dibawa kedalam kelas, peristiwa yang berbahaya untuk diamati seperti gerhana matahari. Waktu dan biaya dari kunjungan lapangan bisa dihindari.

Dari beberapa pendapat ahli di atas, peneliti menyimpulkan bahwa video tutorial adalah adalah rangkaian gambar hidup yang ditayangkan oleh seorang pengajar yang berisi pesan-pesan pembelajaran untuk membantu pemahaman terhadap suatu materi pembelajaran sebagai bimbingan atau bahan pengajaran tambahan kepada sekelompok kecil peserta didik.

\section{Camtasia Studio}

Dahtul (2013) menjelaskan bahwa Camtasia Studio adalah sebuah studio video yang berisi beberapa konversi mengedit, merekam dan menangkap alat untuk desain profesional video, demo dan presentasi. Dengan antarmuka yang disempurnakan diharapkan pengguna baru akan lebih mudah belajar. Pada penelitian ini peneliti menggunakan aplikasi camtasia studio versi 8 .

\section{Macromedia Flash}

Menurut Madcom (2004:12) Macromedia Flash 8.0 adalah program grafis yang diperuntukan untuk motion atau gerak dan dilengkapi dengan script untuk programming (action script) dengan program ini memungkinkan pembuatan animasi media interaktif, game. Macromedia Flash 8.0 dalam pembelajaran itu adalah Macromedia flash 8.0 adalah suatu softwere animasi media pembelajaran untuk membantu guru dalam menyampaikan pembelajaran agar lebih menarik dan mudah di pahami Siswa dan penerapannya 
menggunakan komputer dan imager proyektor. Pada penelitian ini peneliti menggunakan aplikasi macromedia flash versi 8 .

\section{METODE}

Penelitian ini merupakan penelitian dan pengembangan (Research and Development) media pembelajaran, khususnya berupa pembelajaran melalui bahan ajar berbasis multimedia interaktif untuk matakuliah bahasa pemrograman visual pada materi bahasa pemrograman Delphi, yang bersifat lihat, dengar dan praktikkan yang merupakan pengembangan dari model bahan ajar dalam bentuk lain, yang sifatnya melengkapi bahan ajar yang sudah ada. Jadi bukanlah menciptakan media bantuan belajar yang benar-benar baru, dimana seolah-olah belum ada media bantuan belajar berupa CD Interaktif atau computer based learning. Oleh karena itu, kerangka penelitian secara garis besar di tata dengan urutan yakni: mengumpulkan data kondisi saat ini untuk diagnosa kebutuhan, analisis data, mengembangkan dan memilih alternatif tindakan, uji coba model baru, memeriksa reaksi, mengumpulkan data baru untuk diagnosa, mengulangi analisis dan pengembangan, dan merevisi model.

Pada penelitian ini menggunakan model Borg dan Gall yang memiliki lima tahapan dan langkah yang dijabarkan secara ringkas pada tabel 1 di bawah ini.

Tabel 1. Tahapan dan Langkah-Langkah Penelitian

\begin{tabular}{|c|c|c|}
\hline Tahap & Langkah & Aktivitas \\
\hline $\begin{array}{l}\text { Pra Pengembangan } \\
\text { Model }\end{array}$ & 1 & $\begin{array}{l}\text { Penelitian dan pengumpulan data } \\
\text { awal Penelitian pendahuluan Penyusunan hasil } \\
\text { penelitian Pendahuluan Analisa kebutuhan } \\
\text { Perancangan model }\end{array}$ \\
\hline Pengembangan Model & 2 & $\begin{array}{l}\text { Pembuatan bahan ajar berbasis } \\
\text { multimedia interaktif. } \\
\text { - Membuat Struktur Navigasi dan } \\
\text { perancangan halaman } \\
\text { - Membuat naskah (frame) program Merekam } \\
\text { narasi dan mengeditnya dengan program } \\
\text { macromedia flash } \\
\text { - Merekam video menggunakan camtasia } \\
\text { studio } \\
\text { - Mengubah format video AVI menjadi } \\
\text { format file flash video (FLV) dengan } \\
\text { menggunakan program format factory. } \\
\text { - Membuat aplikasi konsep dasar bahasa } \\
\text { pemrograan visual berdasarkan rancangan } \\
\text { halaman yang telah dibuat sebelumnya } \\
\text { - Meng-publish program aplikasi yang telah } \\
\text { selesai ke bentuk CD }\end{array}$ \\
\hline Evaluasi Model & 3 & $\begin{array}{l}\text { Uji coba awal } \\
\text { Kajian dengan ahli materi dan ahli } \\
\text { media Perbaikan }\end{array}$ \\
\hline Penerapan Model & 4 & $\begin{array}{l}\text { Uji Coba Lapangan } \\
\text { Uji coba pada beberapa responden } \\
\text { mahasiswa semester } 2 \text { S } 1 \text { Pendidikan } \\
\text { Informatika STKIP Hamzanwadi Selong }\end{array}$ \\
\hline
\end{tabular}




\begin{tabular}{|c|c|c|}
\hline Revisi Model & 5 & $\begin{array}{l}\text { Perbaikan Operasional Peyempurnaan } \\
\text { berkelanjutan media Pembelajaram berbasis } \\
\text { video CD tutorial interaktif }\end{array}$ \\
\hline
\end{tabular}

Instrumen yang digunakan dalam penelitian ini ditujukan untuk menilai kelayakan media pembelajaran video $\mathrm{CD}$ tutorial interaktif bahasa pemrograman visual. Data yang diperoleh dari angket ini adalah data kuantitatif. Bentuk angket yang digunakan adalah skala bertingkat yaitu sebuah pertanyaan diikuti oleh kolom-kolom yang menunjukkan tingkatan- tingkatan, misalnya mulai dari sangat setuju sampai ke sangat tidak setuju (Arikunto, 2010 : 195). Populasi yang diambil dalam penelitian ini adalah mahasiswa STKIP Hamzanwadi Selong. Sedangkan, sampel penelitian ini adalah satu kelas yaitu Semester 1 dan 3 Prodi Pendidikan Informatika yang diambil secara random berjumlah 30 orang. Data yang diperoleh dalam penelitian ini berupa data deskriptif kuantitatif. Data kuantitatif diperoleh dari penilaian video $\mathrm{CD}$ tutorial interaktif oleh ahli yang menunjukkan kevalidan video tutorial, respon mahasiswa yang menunjukkan kepraktisan video tutorial. Sedangkan instrumen yang digunakan dalam penelitian ini berupa angket yang terdiri dari angket penilaian ahli materi, angket penilaian ahli media, dan angket penilaian mahasiswa.

Teknik ananlisis data dilakukan dengan menggunakan teknik analisis deskriptif kuantitatif, yaitu dengan menganalisis data kuantitatif yang diperoleh dari angket uji ahli dan uji lapangan. Arikunto (1993: 207) menjelaskan bahwa data kuantitatif yang berupa angka-angka hasil perhitungan atau pengukuran diproses dengan cara dijumlah kemudian dibandingkan dengan jumlah yang diharapkan sehingga diperoleh persentase kelayakan. Rumus yang digunakan adalah sebagai berikut:

$$
\text { Persentasi Kelayakan(\%) } \frac{\text { skor yang diobservasi }}{\text { skor yang diharapka }} \text { X 100\% }
$$

Pencarian persentase dimaksudkan untuk mengetahui status sesuatu yang dipersentasekan dan disajikan tetap berupa persentase, tetapi dapat juga persentase kemudian ditafsirkan dengan kalimat yang bersifat kualitatif, misalnya sangat layak (76\% - 100\%), layak (56\% - 75\%), kurang layak (40\% - 55\%), tidak layak (0-39\%). Adapun keempat skala tersebut dapat ditulis dalam tabel 1 skala persentase kelayakan media dibawah ini (Arikunto, 1993:208):

Tabel 2. Skala Persentase Kelayakan

\begin{tabular}{cc}
\hline Persentase Pencapaian & Interpretasi \\
\hline $\mathbf{7 6}-\mathbf{1 0 0} \%$ & Sangat Layak \\
$\mathbf{5 6}-\mathbf{7 5} \%$ & Layak \\
$\mathbf{4 0}-\mathbf{5 5} \%$ & Cukup \\
$\mathbf{0}-\mathbf{3 9} \%$ & Kurang Layak \\
\hline
\end{tabular}

\section{HASIL DAN PEMBAHASAN}

Pengembangan media pembelajaran video tutorial untuk mata kuliah bahasa pemrograman visual didasarkan melalui analisa awal dan akhir. Pengumpulan informasi dilakukan dengan menganalisa permasalahan dan materi yaitu melalui survei pada saat pembelajaran dikelas, kemudian dilanjutkan dengan pengumpulan materi dan pendukungnya. Setelah bahan-bahan terkumpul kemudian dilanjutkan untuk pembuatan media video dengan mendesain (merancang) tampilan media yang kemudian digabungkan/memasukkan 
(assembly) bahan-bahan tersebut sehingga di dapatkan produk video tutorial awal. Video tersebut kemudian divalidasi oleh ahli materi dan ahli media untuk mengetahui kelayakan dari segi materi pelajaran dan segi media pembelajaran.

Uji coba pada mahasiswa dilakukan untuk memperoleh penilaian media dari segi tampilan, pengoperasian dan kemanfaatan media. Tahap validasi dan uji coba dimaksudkan untuk memperoleh masukan atau koreksi tentang produk video tutorial yang telah dihasilkan. Setelah tahapan-tahapan tersebut selesai maka video tutorial siap untuk digunakan dan didistribusikan. Hasil penilaian kelayakan media pembelajaran video tutorial pada mata kuliah bahasa pemrograman visual yang dilakukan oleh ahli materi, ahli media, dan mahasiswa prodi pendidikan informatika semester 2 yaitu :

\section{Hasil Penilaian Ahli Media}

Uji terhadap ahli media digunakan untuk memperoleh validasi kelayakan dari ahli media, dalam penelitian ini diperoleh data ahli media yang terdiri dari tenaga pengajar yang berkompeten dibidangnya. Data yang diperoleh dari hasil validasi ahli media berupa penilaian terhadap media pembelajaran dari aspek media. Validasi oleh ahli media dilakukan dengan menggunakan kuisioner. Untuk memperoleh media pembelajaran yang layak, maka ahli media memberikan saran dan rekomendasi perbaikan. Data hasil penilaian dari ahli media dapat dilihat pada tabel di bawah ini.

Tabel 3. Kelayakan Hasil Penilaian Ahli Media

\begin{tabular}{llllll}
\hline No & Aspek Penilaian & $\mathbf{X t}$ & Yt & \% & Kriteria \\
\hline $\mathbf{1}$ & Tampilan Media & 168 & 200 & 84 & Sangat layak \\
$\mathbf{2}$ & Pemrograman & 170 & 200 & 85 & Sangat layak \\
& $\sum$ & 338 & 400 & 84,5 & Sangat Layak \\
\hline
\end{tabular}

Keterangan:

$\mathrm{Xt}=$ Skor yang diobservasi

$\mathrm{Yt}=$ Skor yang diharapkan

$\%=$ PersentaseKelayakan

Data hasil uji penilaian ahli media pada tabel 2, diuraikan sebagai berikut:

1. Hasil penilaian ahli media terhadap aspek tampilan media pada media pembelajaran video $\mathrm{CD}$ tutorial interaktif bahasa pemrograman visual emperoleh persentase sebesar $84 \%$. Berdasarkan skala persentase pencapaian maka aspek tampilan media termasuk dalam kategori sangat layak.

2. Hasil penilaian ahli media terhadap aspek pemrograman pada media pembelajaran video CD tutorial interaktif bahasa pemrograman visual memperoleh persentase sebesar $85 \%$. Berdasarkan skala persentase pencapaian maka aspek pemrograman termasuk dalam kategori sangat layak.

Secara keseluruhan hasil penilaian ahli media memperoleh persentase sebesar 84,5\%. Berdasarkan skala persentase pencapaian maka media pembelajaran video $\mathrm{CD}$ tutorial interaktif bahasa pemrograman visual termasuk dalam kategori sangat layak sehingga layak digunakan sebagai media pembelajaran.

\section{Hasil Penilaian Ahli Materi}

Uji terhadap ahli materi digunakan untuk memperoleh validasi kelayakan dari ahli materi, dalam penelitian ini diperoleh data dari ahli materi yang terdiri dari tenaga 
pengajar yang berkompeten dibidangnya. Data yang diperoleh dari hasil validasi ahli materi berupa penilaian terhadap media pembelajaran video $\mathrm{CD}$ tutorial interaktif bahasa pemrograman visual dari aspek materi. Validasi oleh ahli media dilakukan dengan menggunakan kuisioner. Untuk memperoleh media pembelajaran yang layak, maka ahli materi memberikan saran dan rekomendasi perbaikan. Data hasil penilaian dari ahli media dapat dilihat pada tabel berikut ini.

Tabel 4. Kelayakan Hasil Penilaian Ahli Materi

\begin{tabular}{lllcll}
\hline No & Aspek Penilaian & $\mathbf{X t}$ & Yt & \% & Kriteria \\
\hline $\mathbf{1}$ & Pembelajaran & 157 & 200 & 78,5 & Sangat layak \\
$\mathbf{2}$ & Isi & 168 & 200 & 84 & Sangat layak \\
& $\sum$ & 325 & 400 & 81,25 & Sangat layak \\
\hline
\end{tabular}

Keterangan:

$\mathrm{Xt}=$ Skor yang diobservasi

$\mathrm{Yt}=$ Skor yang diharapkan

$\%=$ Persentase Kelayakan

Data hasil uji penilaian ahli materi pada tabel 2 sebelumnya diuraikan sebagai berikut:

1. Hasil penilaian ahli materi terhadap aspek pembelajaran pada media pembelajaran video $\mathrm{CD}$ tutorial interaktif bahasa pemrograman visual memperoleh persentase sebesar $78.5 \%$. Berdasarkan skala persentase pencapaian maka aspek pembelajaran termasuk dalam kategori sangat layak.

2. Hasil penilaian ahli materi terhadap aspek isi pada media pembelajaran video CD tutorial interaktif bahasa pemrograman visual memperoleh persentase sebesar $84 \%$. Berdasarkan skala persentase pencapaian maka aspek isi materi termasuk dalam kategori sangat layak.

Secara keseluruhan hasil penilaian ahli materi memperoleh persentase sebesar $81.25 \%$. Berdasarkan skala persentase pencapaian maka media pembelajaran termasuk dalam kategori sangat layak sehingga layak digunakan sebagai media

\section{Hasil Uji Coba Produk}

Uji coba produk dilakukan setelah produk direvisi dan dinyatakan layak oleh ahli media dan ahli materi. Data penilaian pada uji produk ini menggunakan angket. Angket diberikan kepada 30 mahasiswa STKIP Hamzanwadi Selong Program Studi Pendidikan Informatika. Aspek yang dinilai yaitu meliputi aspek materi dan media. Data hasil uji coba produk dapat dilihat pada tabel berikut ini.

Tabel 5. Hasil Penilaiaian Kelayakan Produk

\begin{tabular}{llllll}
\hline No & Aspek Penilaian & $\mathbf{X t}$ & Yt & \% & Kriteria \\
\hline $\mathbf{1}$ & Materi & 1024 & 1200 & 85.33 & Sangat layak \\
$\mathbf{2}$ & Media & 1012 & 1200 & 84.33 & Sangat layak \\
& $\sum$ & 2036 & 2400 & 84.83 & Sangat layak \\
\hline
\end{tabular}

Keterangan:

$\mathrm{Xt}=$ Skor yang diobservasi

$\mathrm{Yt}=$ Skor yang diharapkan

$\%=$ Persentase Kelayakan 
Data hasil uji coba produk pada gambar di atas diuraikan sebagai berikut:

1. Hasil penilaian mahasiswa terhadap aspek materi pada media pembelajaran video $\mathrm{CD}$ tutorial interaktif bahasa pemrograman visual memperoleh persentase sebesar $85.33 \%$. Berdasarkan skala persentase pencapaian maka aspek materi termasuk dalam kategori sangat layak.

2. Hasil penilaian mahasiswa terhadap aspek media pada media pembelajaran video $\mathrm{CD}$ tutorial interaktif bahasa pemrograman visual memperoleh persentase sebesar $84.33 \%$. Berdasarkan skala persentase pencapaian maka aspek media termasuk dalam kategori sangat layak. Secara keseluruhan hasil penilaian mahasiswa memperoleh persentase sebesar $84.83 \%$. Berdasarkan skala persentase pencapaian maka media pembelajaran termasuk dalam kategori sangat layak sehingga layak digunakan sebagai media pembelajaran.

Dengan melihat hasil uji ahli media pembelajaran, ahli materi pembelajaran, dan uji coba media pembelajaran dapat disimpulkan bahwa media pembelajaran pembelajaran ini layak digunakan sebagai media pembelajaran video $\mathrm{CD}$ tutorial interaktif bahasa pemrograman visual. Sehingga diharapkan penggunaan media pembelajaran video tutorial ini efektif dikarenakan video tutorial memiliki beberapa keunggulan jika dibandingkan dengan metode pembelajaran langsung yang dilakukan dosen menggunakan gambar yaitu: (1) tampilan video yang menarik dilengkapi dengan musik membuat mahasiswa lebih termotivasi untuk belajar, (2) mahasiswa dapat dengan mudah mengulang kembali bagian yang dianggapnya belum jelas sehingga mahasiswa dapat belajar secara mandiri, dan (3) video tutorial ini juga mudah untuk digunakan (user friendly).

\section{SIMPULAN}

Berdasarkan pembahasan di atas, dapat disimpulkan bahwa: (1) Media pembelajaran berbasis video $\mathrm{CD}$ tutorial interaktif ini dapat menjadi suplemen bagi mahasiswa walaupun sifatnya hanya pilihan tapi dapat dimanfaatkan juga untuk menambah pengetahuan, wawasan khususnya tentang matakuliah bahasa pemrograman visual materi bahasa pemrograman delphi serta memudahkan proses belajar mengajar serta meningkatkan kualitas pembelajaran dan prestasi belajar mahasiswa, (2) Hasil pengisian kuesioner dari 30 responden mahasiswa mengenai kualitas tampilan materi, penyajian materi, interaksi pemakai, interaksi program dan aspek desain memperoleh persentase sebesar $84.83 \%$. Berdasarkan skala persentase pencapaian maka media pembelajaran video $\mathrm{CD}$ tutorial interaktif termasuk dalam kategori sangat layak sehingga layak digunakan sebagai media pembelajaran bersifat pilihan yang dapat membantu mahasiswa meningkatkan prestasi belajar mahasiswa.

\section{REFERENSI}

Alfiah, R. (2008). Pengembangan Media Pembelajaran Matematika Menggunakan Macromedia Flash Profesional 8 sebagai Sumber Belajar bagi Siswa SMA/MA Kelas XII Semester 1 untuk Materi Pokok Tranformasi Geometri. Skripsi.FKIP. UIN Sunan Kalijaga.

Arikunto, S. (1993). Prosedur Penelitian Suatu Pendekatan Praktik (edisi revisi). Jakarta: Rineka Cipta.

Arikunto, S. (2010). Prosedur Penelitian Suatu Pendekatan Praktik. Jakarta: Rineka Cipta. 
Arsyad, A. (2006). Media Pembelajaran. Jakarta: PT. Raja Grafindo Persada.

Arsyad, A. (2011). Media Pembelajaran.Jakarta: PT. Raja Grafindo Persada.

Daryanto. (2011). Media Pembelajaran.Bandung: PT S a r a n a Tutorial Nurani Sejahtera.

Ilmawan, M. (2004). Rancang Bangun Modul Input Output Programmable Logic Controller Berbasis Mikrokontroler sebagai Media Pembelajaran Praktik Kendali Terprogram. Skripsi, Tidak diterbitkan.

Lowther, D. L, Russell, J. D, Smaldino, S. E. (2011). Instructional Technology \& Media For Learning Teknologi Pembelajaran dan Media untuk Belajar (Terjemahan. Edisi Kesembilan). Jakarta: Kencana Prenada Media Group.

Madcoms. (2003). Pemrograman Borland Delphi 7. Yogyakarta: Andi.

Purbaya, E. W. (2010). Pengembangan CD Pembelajaran Kimia Menggunakan Adobe Flash CS3 Sebagai Sumber Belajar Bagi Siswa Sma/Ma Kelas X Semester 1 Materi Pokok Sistem Periodik Unsur. Skripsi. FKIP. UIN Sunan Kalijaga.

Riyana, C. (2007). Pedoman Pengembangan Media Video. Jakarta: P3AI UPI.

Setiabudi, N.W. (2005). Pengembangan Media Pembelajaran Berbasis Multimedia Untuk Mata Pelajaran Fisika Bahasan Kinematika Gerak Lurus. Skripsi. Fakultas Teknik. Universitas Negeri Semarang.

Sudjana, N., dan Rivai, A. (2005). Media Pengajaran (Penggunaan dan Pembuatannya). Bandung: Sinar Baru Algensindo.

Tim Redaksi Pusat Bahasa Depdiknas (2001). Kamus Besar Bahasa Indonesia (Edisi ketiga). Jakarta: Balai Pustaka. 